\title{
The engineered peptide construct NCAM1-A $\beta$ inhibits aggregation of the human prion protein (PrP)
}

Maciej Gielnik ${ }^{1}$, Lilia Zhukova ${ }^{2}$, Igor Zhukov ${ }^{2}$, Astrid Gräslund ${ }^{3}$, Maciej Kozak ${ }^{1,4}$, Sebastian K.T.S. Wärmländer ${ }^{3, *}$

${ }^{1}$ Department of Macromolecular Physics, Adam Mickiewicz University, Poznań, Poland; maciejgielnik@amu.edu.pl (M.G.); mkozak@amu.edu.pl (M.K.)

${ }^{2}$ Institute of Biochemistry and Biophysics, Polish Academy of Sciences, Warszawa, Poland; lilia@ibb.waw.pl (L.Z.); igor@ibb.waw.pl (I.Z.)

${ }^{3}$ Department of Biochemistry and Biophysics, Arrhenius Laboratories, Stockholm University, 10691 Stockholm, Sweden; astrid@dbb.su.se (A.G.); seb@dbb.su.se (S.W.)

${ }^{4}$ National Synchrotron Radiation Centre SOLARIS, Jagiellonian University, Kraków, Poland.

* Correspondence: seb@dbb.su.se; Tel.: +46-8-16 2444

\begin{abstract}
In prion diseases, the prion protein ( $\mathrm{PrP}$ ) becomes misfolded and forms fibrillar aggregates, which are resistant to proteinase degradation and become responsible for prion infectivity and pathology. So far, no drug or treatment procedures have been approved for prion disease treatment. We have previously shown that engineered cell-penetrating peptide constructs can reduce the amount of prion aggregates in infected cells. The molecular mechanisms underlying this effect are however unknown. Here, we use atomic force microscopy (AFM) imaging to show that the aggregation of the human PrP protein can be inhibited by equimolar amounts of the 25 residues long engineered peptide construct NCAM1-A $\beta$.
\end{abstract}

Keywords: Creutzfeldt-Jakob disease; AFM imaging; amyloid; drug design; drug transport; protein-peptide binding 


\section{Introduction}

Prion and amyloid diseases are both characterized by aggregation of misfolded proteins or peptides (Jaunmuktane and Brandner, 2019; Miller, 2009; Sengupta and Udgaonkar, 2018; Verma et al., 2015), such as the prion (PrP) protein (CreutzfeldtJakob disease), $\alpha$-synuclein (Parkinson's disease), and amyloid- $\beta$ (A $\beta$ ) and tau (Alzheimer's disease). Many of these proteins and peptides may co-aggregate or at least influence each other's aggregation (Luo et al., 2016, 2017; Ren et al., 2019; Wallin et al., 2018). Factors that modulate the aggregation of one of these proteins, such as small molecules, potential drug compounds, lipids, and metal ions, can often modulate also the aggregation processes of other proteins in this family (Ambadi Thody et al., 2018; Chemerovski-Glikman et al., 2016; Gielnik et al., 2019; Owen et al., 2019; Richman et al., 2013; Robinson and Pinheiro, 2010; Wallin et al., 2017; Wärmländer et al., 2013; Wärmländer et al., 2019; Österlund et al., 2018). This suggests that the underlying mechanisms may be the same in prion and amyloid diseases (Jaunmuktane and Brandner, 2019; Jucker and Walker, 2018; Miller, 2009). Prion aggregates are however particularly infectious, as they spread between cells (Jaunmuktane and Brandner, 2019; Jucker and Walker, 2018), and are not degraded by cellular processes such as proteinase digestion (Jaunmuktane and Brandner, 2019; Löfgren et al., 2008; Söderberg et al., 2014).

The toxic species in amyloid and prion diseases are generally considered to be small toxic oligomeric aggregates (Sengupta and Udgaonkar, 2018; Verma et al., 2015), but so far no drugs or treatments that target such aggregates have been approved against prion diseases (Hyeon et al., 2020; Lee et al., 2019; Mashima et al., 2020). Potential drug molecules may interfere with oligomer formation in various ways: by reducing production of the protein, by inhibiting its aggregation, by diverting the aggregation pathway(s) towards non-toxic forms, or by reducing the lifetime of the toxic forms, for example by promoting rapid aggregation into larger non-toxic aggregates. We have previously demonstrated anti-prion properties in short peptide constructs (up to 30 residues) with sequences derived from the unprocessed N-termini of mouse and 
bovine prion proteins: such PrP-derived peptides induced lower amounts of prion aggregates resistant to proteinase $\mathrm{K}$ in prion-infected cells (Löfgren et al., 2008; Söderberg et al., 2014).

The PrP-derived peptides consisted of an N-terminal signal peptide segment (different for mouse and bovine PrP), together with a conserved positively charged and hydrophobic hexapeptide (KKRPKP) corresponding to the first six residues of the processed PrP protein. Our earlier studies had shown that peptides with such sequences were able to interact with and penetrate cell membranes (Lundberg et al., 2002; Magzoub et al., 2005; Magzoub et al., 2006; Oglecka et al., 2008). The antiprion effects of the PrP-derived peptides were lost when the KKRPKP hexapeptide was coupled to various peptides with cell-penetrating properties (Söderberg et al., 2014). The anti-prion effects were however retained when KKRPKP was coupled to the signal sequence of the Neural cell adhesion molecule-1 (i.e., NCAM1 1-19) (Söderberg et al., 2014).

The mouse $\mathrm{PrP}_{1-28}$ segment and the NCAM1 $1_{1-19}-\mathrm{KKRPKP}$ construct are both amyloidogenic in themselves, as they form amyloid fibrils by self-aggregation (Mukundan et al., 2017; Pansieri et al., 2019). The NCAM1 1-19-KKRPKP construct was recently shown to inhibit aggregation of the amyloid- $\beta$ peptide involved in Alzheimer's disease (Henning-Knechtel et al., 2020), and to promote in vitro aggregation of the amyloid protein S100A9 (Pansieri et al., 2019), which is involved in amyloid-related and other inflammatory processes (Horvath et al., 2018; Wang et al., 2019; Wang et al., 2014). Almost identical results were obtained for a similar amyloidogenic 25 residue-construct, i.e. NCAM1 1-19-KKLVFF (from here onwards: NCAM1-A $\beta$ ) (Pansieri et al., 2019). The KLVFF sequence originates from the hydrophobic core (residues 16-20) of the A $\beta$ peptide: this pentapeptide is known to inhibit aggregation of the full-length $A \beta$ peptide (Tjernberg et al., 1996). In the NCAM1-A $\beta$ construct, an additional lysine residue was added to the KLVFF sequence for increased solubility (Pansieri et al., 2019). The molecular properties of the NCAM1-A $\beta$ sequence and its segments are shown in Table 1, including 
hydrophobicity values calculated according to the Wimley-White whole residue hydrophobicity scale (Wang et al., 2016; Wimley and White, 1996).

As the NCAM1-A $\beta$ construct inhibits fibrillation of the A $\beta$ peptide (HenningKnechtel et al., 2020), but promotes (co-)aggregation of the S100A9 protein (Pansieri et al., 2019), it is unclear how the construct may affect the aggregation of the PrP protein (if at all). Here, we use Atomic Force Microscopy (AFM) imaging to investigate if there is a direct effect of the NCAM1-A $\beta$ construct on the in vitro aggregation of the human $\operatorname{PrP}$ protein. Answering this question might help clarify the mechanisms underlying the previously observed beneficial effects of such peptide constructs on PrP infectivity (Löfgren et al., 2008; Söderberg et al., 2014).

Table 1. Primary sequences and molecular properties of the human PrP protein, the NCAM1-A $\beta$ peptide construct, and its parts.

\begin{tabular}{|c|c|c|c|c|c|}
\hline Protein & Sequence & $\begin{array}{l}\text { Isoelectric } \\
\text { point (pI) }\end{array}$ & $\begin{array}{c}\text { Molecular } \\
\text { weight } \\
{\left[\mathrm{g} \mathrm{mol}^{-1}\right]}\end{array}$ & $\begin{array}{c}\text { Net } \\
\text { charge } \\
\text { at pH } \\
7\end{array}$ & $\begin{array}{c}\text { Theoretical } \\
\text { hydrophobicity } \\
{\left[\mathrm{kcal} \mathrm{mol}^{-1}\right]}\end{array}$ \\
\hline huPrP $23-231$ & $\begin{array}{l}\text { UniProt ID: P04156 } \\
\text { (209 aa) }\end{array}$ & 9.39 & 22747 & +7 & - \\
\hline $\begin{array}{l}\text { NCAM1 1-19-K- } \\
\underline{A \beta_{16-20}}(\text { NCAM1- } \\
A \beta)\end{array}$ & $\begin{array}{l}\mathbf{N H}_{2} \text {-MLRTKDLIWTL } \\
\text { FFLGTAVSKKLVFF- } \\
\mathbf{N H}_{\mathbf{2}}\end{array}$ & 11.67 & 2974.7 & +4 & -3.83 \\
\hline $\begin{array}{l}\text { NCAM1 }_{1-19} \\
\text { (NCAM1) }^{\text {NCAM }}\end{array}$ & $\begin{array}{l}\mathbf{N H}_{2} \text {-MLRTKDLIWTL } \\
\text { FFLGTAVS-NH }\end{array}$ & 11.39 & 2211.7 & +2 & -3.06 \\
\hline KKLVFF & $\mathbf{N H}_{2}$-KKLVFF-COOH & 10.69 & 781 & +2 & -0.77 \\
\hline
\end{tabular}




\section{Materials and Methods}

\subsection{Sample preparation}

Human recombinant prion protein (huPrP) was prepared according to a previously published protocol (Morillas et al., 1999; Zahn et al., 1997), albeit with some modifications. The plasmid contained the full-length (23-231)huPrP protein in fusion with an N-terminal HisTag, and the thrombin cleavage site was cloned into the pRSETB vector (Invitrogen, USA). The construct was expressed in E. Coli (BL21DE3) grown in LB growth medium with $100 \mu \mathrm{g} / \mathrm{mL}$ ampicillin. Expression was induced by isopropyl $\beta$-D-galactopyranoside (IPTG) at $\mathrm{OD}_{600}=0.8$. Sonication of the lysates was performed in a buffer containing $100 \mathrm{mM}$ Tris at $\mathrm{pH} 8,10 \mathrm{mM} \mathrm{K}_{2} \mathrm{HPO}_{4}$, $10 \mathrm{mM}$ glutathione (GSH), $6 \mathrm{M} \mathrm{GuHCl}$, and $0.5 \mathrm{mM}$ phenylmethane sulfonyl fluoride (PMSF). The solution was centrifuged and the supernatant loaded to Ni-NTA resin (GE Healthcare) and eluted with buffer E (100 mM Tris at pH 5.8, $10 \mathrm{mM} \mathrm{K}_{2} \mathrm{HPO}_{4}$, and $500 \mathrm{mM}$ imidazole). After washing the resin, the protein was purified with twostep dialysis, initially against $10 \mathrm{mM}$ phosphate buffer with $0.1 \mathrm{mM}$ PMSF at $\mathrm{pH} 5.8$, and then against Milli-Q $\mathrm{H}_{2} \mathrm{O}$ with $0.1 \mathrm{mM}$ PMSF. After thrombin cleavage, the pure huPrP protein (i.e., with the HisTag removed) was concentrated using an Amicon Ultra $0.5 \mathrm{ml}$ centrifugal filter (Merck \& Co., USA) with an NMWL cutoff of $3 \mathrm{kDa}$. The final protein concentration was determined by spectrophotometry using an extinction coefficient of $\varepsilon_{280}=57995 \mathrm{M}^{-1} \mathrm{~cm}^{-1}$ (Gasteiger et al., 2005). The quality of the final protein was controlled by mass spectrometry (molecular mass $22747 \mathrm{Da}$ Table 1).

The NCAM1-A $\beta$ peptide (Table 1) was purchased as a custom order from the PolyPeptide Group (France) in lyophilized form. The peptide was dissolved in Milli-Q water, and its concentration was determined via triplicate UV absorption measurements at $280 \mathrm{~nm}$, using a DS-11 spectrophotometer (DeNovix, USA) and an extinction coefficient of $\varepsilon_{280}=5500 \mathrm{M}^{-1} \mathrm{~cm}^{-1}$ (Gasteiger et al., 2005). 


\subsection{Sample incubation}

The initial buffer in the huPrP solution was exchanged to ultrapure water by triplicate diafiltration using an Amicon Ultra $0.5 \mathrm{ml}$ centrifugal filter (Merck \& Co., USA) with an NMWL cutoff of $3 \mathrm{kDa}$. Samples of $0.5 \mu \mathrm{M}$ NCAM1-A $\beta, 2.5 \mu \mathrm{M}$ NCAM1-A $\beta$, $0.5 \mu \mathrm{M}$ huPrP, and $0.5 \mu \mathrm{M}$ NCAM1-A $\beta+0.5 \mu \mathrm{M}$ huPrP were then prepared in 10 $\mathrm{mM}$ sodium phosphate buffer, $\mathrm{pH} 7.5$, with $100 \mathrm{mM} \mathrm{NaCl}$ and $2 \mathrm{M}$ urea. The urea was added as it has previously been shown to promote unfolding of the native PrP structure, which is the first step towards aggregation (Julien et al., 2009; Swietnicki et al., 2000). The samples were incubated for 72 hours at $50{ }^{\circ} \mathrm{C}$ with magnetic stirring at 400 rpm. Subsamples were taken out for AFM imaging (below) after 8 and 72 hours, respectively.

\subsection{Atomic force microscopy (AFM) imaging}

Incubated samples $(5 \mu 1)$ were transferred to freshly cleaved mica plates and left to absorb for $1 \mathrm{~min}$, rinsed three times with $300 \mu \mathrm{l}$ of pure water, and then dried under a gentle flow of nitrogen. AFM imaging was performed on a JPK Nanowizard 4 (Bruker, Germany) AFM unit using Tap150Al-G cantilevers (Ted Pella Inc., USA) in air intermittent contact mode. The scan rate was $0.3-0.7 \mathrm{~Hz}$, the scan area size was 5 $\mu \mathrm{m} \times 5 \mu \mathrm{m}$ or $10 \mu \mathrm{m}$ x $10 \mu \mathrm{m}$, with 512 x 512 or 1024 x 1024 pixel resolution respectively. The AFM images were analyzed using the Gwyddion 2.54 software (Necas and Klapetek, 2012).

\section{Results and Discussion}

AFM images of the aggregation products present in the samples after 8 hours of incubation are shown in Figs. 1A-D. The sample of $0.5 \mu \mathrm{M}$ huPrP readily selfaggregated into long fibrils (Fig. 1A) that are approximately 3 - $4 \mathrm{~nm}$ thick (judged by their measured height, as width is not accurately represented in AFM images). This is somewhat thinner but still in line with the results of previous studies on PrP fibrils (Terry and Wadsworth, 2019; Vazquez-Fernandez et al., 2017; Yamaguchi and Kuwata, 2018). A few very large aggregate clumps, over $10 \mathrm{~nm}$ high, can also be seen (Fig. 1A). For NCAM1-A $\beta$, the $0.5 \mu \mathrm{M}$ sample shows small aggregate clumps (Fig 
1B). Some of them are relatively large, with heights over $6 \mathrm{~nm}$, and may or may not be early stages of fibrillar aggregates (Luo et al., 2014). The $2.5 \mu \mathrm{M}$ NCAM1-A $\beta$ sample shows numerous mature fibrils, about $2-3 \mathrm{~nm}$ high, together with aggregate clumps (Fig. 1C). The more abundant amount of fibrils for $2.5 \mu \mathrm{M}$ of NCAM1-A $\beta$ confirms earlier results showing that NCAM1-A $\beta$ self-aggregates faster at higher concentrations (Pansieri et al., 2019).
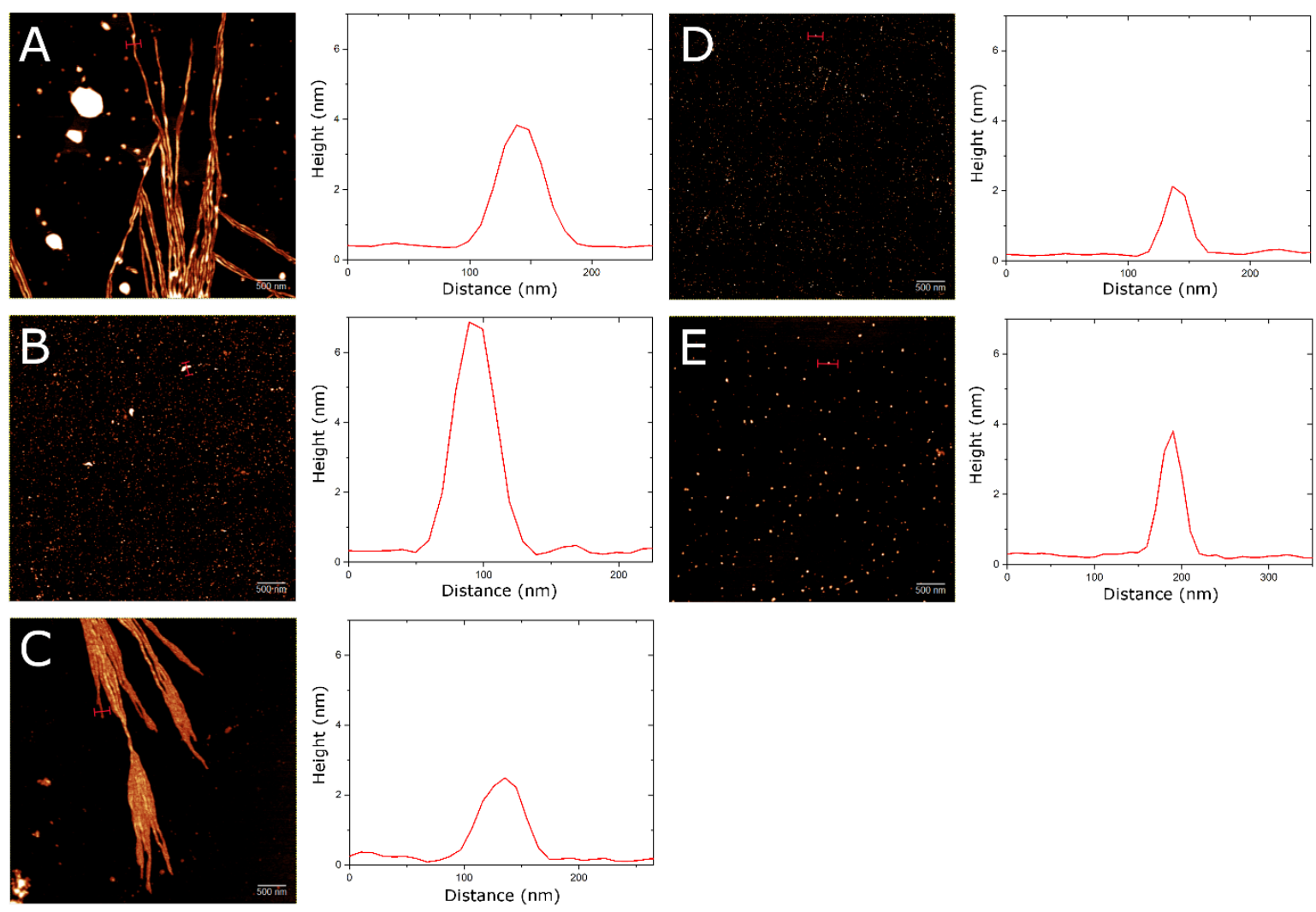

Figure 1. AFM images of: (A) $0.5 \mu \mathrm{M}$ huPrP protein; (B) $0.5 \mu \mathrm{M}$ NCAM1-A $\beta$ peptide; (C) $2.5 \mu \mathrm{M}$ NCAM1-A $\beta$ peptide; and (D) $0.5 \mu \mathrm{M}$ huPrP protein $+0.5 \mu \mathrm{M}$ NCAM1-A $\beta$ peptide. All samples in A-D were incubated for 8 hours. (E) $0.5 \mu \mathrm{M}$ huPrP protein $+0.5 \mu \mathrm{M}$ NCAM1-A $\beta$ peptide, incubated for 72 hours. All studied samples were incubated at $50{ }^{\circ} \mathrm{C}$ in $10 \mathrm{mM}$ sodium phosphate buffer, $\mathrm{pH} 7.5$, with 100 $\mathrm{mM} \mathrm{NaCl}$ and $2 \mathrm{M}$ urea, and with magnetic stirring at $400 \mathrm{rpm}$. The white scale bars are $500 \mathrm{~nm}$. 
Interestingly, the sample containing both $0.5 \mu \mathrm{M}$ NCAM1-A $\beta$ and $0.5 \mu \mathrm{M}$ huPrP displays no fibrils, but only numerous small aggregate clumps, about $2 \mathrm{~nm}$ high (Fig. 1D). Even after 72 hours no fibrils can be seen, but the aggregate clumps are then fewer and larger, around 3-4 nm high (Fig 1E). As it cannot be ruled out that these small aggregate clumps will eventually form fibrils, it is not possible to tell if fibrillation is completely inhibited, or if the fibrillation rate merely is significantly reduced. Nonetheless, the absence of fibrillar aggregates of huPrP in the presence of equimolar concentrations of NCAM1-A $\beta$ clearly shows that the peptide construct directly interacts with the huPrP protein and interferes with its aggregation. As both molecules are positively charged (Table 1), it stands to reason that they interact mainly via hydrophobic forces.

The aggregation-inhibiting effect of NCAM1-A $\beta$ (Fig. 1) appears to provide an explanation, at a molecular level, to our earlier observations that such peptide constructs significantly reduce the levels of prion aggregates in prion-infected cells (Löfgren et al., 2008; Söderberg et al., 2014). As both the NCAM1-A $\beta$ peptide and the huPrP protein can form amyloid fibrils by themselves (Figs. 1A and 1C), the two molecules may interact via cross-aggregation, to form smaller non-fibrillar coaggregates (Fig. 1E) that could be less toxic than pure huPrP aggregates (Luo et al., 2016, 2017). If so, the huPrP/NCAM1-A $\beta$ interactions would be similar to the interactions between $A \beta$ and NCAM1-A $\beta$ (Henning-Knechtel et al., 2020). In any case, the huPrP/NCAM1-A $\beta$ interactions are very different from the interactions between NCAM1-A $\beta$ and S100A9 protein, where amyloid aggregation is promoted (Pansieri et al., 2019). Because the NCAM1-A $\beta$ construct has different effects on different aggregating proteins, it would be interesting to study how this construct might affect the aggregation of other disease-related prion proteins, such as those involved in animal diseases like bovine spongiform encephalopathy (BSE), chronic wasting disease in cervids, and sheep scrapie (Vazquez-Fernandez et al., 2017). 


\section{Conclusions}

Our atomic force microscopy images show that the in vitro aggregation of the human PrP protein is inhibited by equimolar amounts of the 25 residues long engineered peptide NCAM1-A $\beta$. Thus, a very likely molecular-level explanation to our previous observation that such cell-penetrating peptide constructs can reduce the amount of prion aggregates in infected cells, is that these peptide constructs directly interact with the PrP protein and prevent its fibrillation.

Funding: The research of MG, IZ, LZ and MK was supported by an OPUS research grant (2014/15/B/ST4/04839) from the National Science Centre (Poland). AG was supported by grants from the Swedish Research Council and from Byggmästare Engkvist's Foundation.

Conflicts of Interest: The authors declare no conflict of interests. 


\section{References}

Ambadi Thody, S., Mathew, M.K., Udgaonkar, J.B., 2018. Mechanism of aggregation and membrane interactions of mammalian prion protein. Biochim Biophys Acta Biomembr.

Chemerovski-Glikman, M., Rozentur-Shkop, E., Richman, M., Grupi, A., Getler, A., Cohen, H.Y., Shaked, H., Wallin, C., Wärmländer, S.K., Haas, E., Gräslund, A., Chill, J.H., Rahimipour, S., 2016. Self-Assembled Cyclic d,I-alpha-Peptides as Generic Conformational Inhibitors of the alpha-Synuclein Aggregation and Toxicity: In Vitro and Mechanistic Studies. Chemistry 22, 14236-14246.

Gasteiger, E., Hoogland, C., Gattiker, A., Duvaud, S.e., Wilkins, M.R., Appel, R.D., Amos, B., 2005. Protein Identification and Analysis Tools on the ExPASy Server, in: Walker, J.M. (Ed.), The Proteomics Protocols Handbook. Humana Press, pp. 571-607.

Gielnik, M., Pietralik, Z., Zhukov, I., Szymańska, A., Kwiatek, W.M., Kozak, M., 2019. PrP (58-93) peptide from unstructured $\mathrm{N}$-terminaldomain of human prion protein forms amyloidlikefibrillar structures in the presence of Zn2+ions. RSC Advances 9, 22211-22219.

Henning-Knechtel, A., Kumar, S., Wallin, C., Król, S., Wärmländer, S., Jarvet, J., Esposito, G., Kirmizialtin, S., Gräslund, A., Hamilton, A.D., Magzoub, M., 2020. Designed cell-penetrating peptide inhibitors of amyloid-beta aggregation and cytotoxicity. Cell Reports Physical Science 1, 100014.

Horvath, I., lashchishyn, I.A., Moskalenko, R.A., Wang, C., Wärmländer, S.K.T.S., Wallin, C., Gräslund, A., Kovacs, G.G., Morozova-Roche, L.A., 2018. Co-aggregation of pro-inflammatory S100A9 with alpha-synuclein in Parkinson's disease: ex vivo and in vitro studies. J Neuroinflammation $15,172$.

Hyeon, J.W., Noh, R., Choi, J., Lee, S.M., Lee, Y.S., An, S.S.A., No, K.T., Lee, J., 2020. BMD42-2910, a Novel Benzoxazole Derivative, Shows a Potent Anti-prion Activity and Prolongs the Mean Survival in an Animal Model of Prion Disease. Exp Neurobiol 29, 93-105.

Jaunmuktane, Z., Brandner, S., 2019. The role of prion-like mechanisms in neurodegenerative diseases. Neuropathol Appl Neurobiol.

Jucker, M., Walker, L.C., 2018. Propagation and spread of pathogenic protein assemblies in neurodegenerative diseases. Nat Neurosci 21, 1341-1349.

Julien, O., Chatterjee, S., Thiessen, A., Graether, S.P., Sykes, B.D., 2009. Differential stability of the bovine prion protein upon urea unfolding. Protein Sci 18, 2172-2182.

Kristensen, M., Birch, D., Morck Nielsen, H., 2016. Applications and Challenges for Use of CellPenetrating Peptides as Delivery Vectors for Peptide and Protein Cargos. Int J Mol Sci 17.

Lee, S.M., Kim, S.S., Kim, H., Kim, S.Y., 2019. THERPA v2: an update of a small molecule database related to prion protein regulation and prion disease progression. Prion 13, 197-198.

Lundberg, P., Magzoub, M., Lindberg, M., Hallbrink, M., Jarvet, J., Eriksson, L.E., Langel, U., Gräslund, A., 2002. Cell membrane translocation of the $\mathrm{N}$-terminal (1-28) part of the prion protein. Biochem Biophys Res Commun 299, 85-90.

Luo, J., Wärmländer, S.K., Gräslund, A., Abrahams, J.P., 2014. Alzheimer peptides aggregate into transient nanoglobules that nucleate fibrils. Biochemistry 53, 6302-6308.

Luo, J., Wärmländer, S.K., Gräslund, A., Abrahams, J.P., 2016. Reciprocal Molecular Interactions between the Abeta Peptide Linked to Alzheimer's Disease and Insulin Linked to Diabetes Mellitus Type II. ACS Chem Neurosci 7, 269-274.

Luo, J., Wärmländer, S.K., Gräslund, A., Abrahams, J.P., 2017. Cross-interactions between the Alzheimer disease amyloid-beta peptide and other amyloid proteins. A FURTHER ASPECT OF THE AMYLOID CASCADE HYPOTHESIS. J Biol Chem 292, 2046.

Löfgren, K., Wahlström, A., Lundberg, P., Langel, U., Gräslund, A., Bedecs, K., 2008. Antiprion properties of prion protein-derived cell-penetrating peptides. FASEB J 22, 2177-2184. 
Magzoub, M., Oglecka, K., Pramanik, A., Eriksson, G.L.E., Gräslund, A., 2005. Membrane perturbation effects of peptides derived from the $\mathrm{N}$-termini of unprocessed prion proteins. Biochim Biophys Acta 1716, 126-136.

Magzoub, M., Sandgren, S., Lundberg, P., Oglecka, K., Lilja, J., Wittrup, A., Eriksson, G.L.E., Langel, U., Belting, M., Gräslund, A., 2006. N-terminal peptides from unprocessed prion proteins enter cells by macropinocytosis. Biochem Biophys Res Commun 348, 379-385.

Mashima, T., Lee, J.H., Kamatari, Y.O., Hayashi, T., Nagata, T., Nishikawa, F., Nishikawa, S., Kinoshita, M., Kuwata, K., Katahira, M., 2020. Development and structural determination of an anti$\operatorname{PrP}(C)$ aptamer that blocks pathological conformational conversion of prion protein. Sci Rep 10, 4934.

Miller, G., 2009. Neurodegeneration. Could they all be prion diseases? Science 326, 1337-1339.

Morillas, M., Swietnicki, W., Gambetti, P., Surewicz, W.K., 1999. Membrane environment alters the conformational structure of the recombinant human prion protein. J Biol Chem 274, 3685936865.

Mukundan, V., Maksoudian, C., Vogel, M.C., Chehade, I., Katsiotis, M.S., Alhassan, S.M., Magzoub, M., 2017. Cytotoxicity of prion protein-derived cell-penetrating peptides is modulated by $\mathrm{pH}$ but independent of amyloid formation. Arch Biochem Biophys 613, 31-42.

Necas, D., Klapetek, P., 2012. Gwyddion: an open-source software for SPM data analysis. Central European Journal of Physics 10, 181-188.

Oglecka, K., Lundberg, P., Magzoub, M., Eriksson, G.L.E., Langel, U., Gräslund, A., 2008. Relevance of the N-terminal NLS-like sequence of the prion protein for membrane perturbation effects. Biochim Biophys Acta 1778, 206-213.

Owen, M.C., Gnutt, D., Gao, M., Wärmländer, S.K.T.S., Jarvet, J., Gräslund, A., Winter, R., Ebbinghaus, S., Strodel, B., 2019. Effects of in vivo conditions on amyloid aggregation. Chem Soc Rev 48, 3946-3996.

Pansieri, J., Ostojic, L., lashchishyn, I.A., Magzoub, M., Wallin, C., Wärmländer, S., Gräslund, A., Nguyen Ngoc, M., Smirnovas, V., Svedruzic, Z., Morozova-Roche, L.A., 2019. ProInflammatory S100A9 Protein Aggregation Promoted by NCAM1 Peptide Constructs. ACS Chem Biol 14, 1410-1417.

Ren, B., Zhang, Y., Zhang, M., Liu, Y., Zhang, D., Gong, X., Feng, Z., Tang, J., Chang, Y., Zheng, J., 2019. Fundamentals of cross-seeding of amyloid proteins: an introduction. J Mater Chem B 7, 7267-7282.

Richman, M., Wilk, S., Chemerovski, M., Wärmländer, S.K., Wahlström, A., Gräslund, A., Rahimipour, S., 2013. In vitro and mechanistic studies of an antiamyloidogenic self-assembled cyclic D, Lalpha-peptide architecture. J Am Chem Soc 135, 3474-3484.

Robinson, P.J., Pinheiro, T.J., 2010. Phospholipid composition of membranes directs prions down alternative aggregation pathways. Biophys J 98, 1520-1528.

Santuccione, A., Sytnyk, V., Leshchyns'ka, I., Schachner, M., 2005. Prion protein recruits its neuronal receptor NCAM to lipid rafts to activate p59fyn and to enhance neurite outgrowth. J Cell Biol 169, 341-354.

Schmitt-Ulms, G., Legname, G., Baldwin, M.A., Ball, H.L., Bradon, N., Bosque, P.J., Crossin, K.L., Edelman, G.M., DeArmond, S.J., Cohen, F.E., Prusiner, S.B., 2001. Binding of neural cell adhesion molecules (N-CAMs) to the cellular prion protein. J Mol Biol 314, 1209-1225.

Sengupta, I., Udgaonkar, J.B., 2018. Structural mechanisms of oligomer and amyloid fibril formation by the prion protein. Chem Commun (Camb) 54, 6230-6242.

Swietnicki, W., Morillas, M., Chen, S.G., Gambetti, P., Surewicz, W.K., 2000. Aggregation and fibrillization of the recombinant human prion protein huPrP90-231. Biochemistry 39, 424431.

Söderberg, K.L., Guterstam, P., Langel, U., Gräslund, A., 2014. Targeting prion propagation using peptide constructs with signal sequence motifs. Arch Biochem Biophys 564, 254-261. 
Terry, C., Wadsworth, J.D.F., 2019. Recent Advances in Understanding Mammalian Prion Structure: A Mini Review. Front Mol Neurosci 12, 169.

Tjernberg, L.O., Näslund, J., Lindqvist, F., Johansson, J., Karlström, A.R., Thyberg, J., Terenius, L., Nordstedt, C., 1996. Arrest of beta-amyloid fibril formation by a pentapeptide ligand. J Biol Chem 271, 8545-8548.

Vazquez-Fernandez, E., Young, H.S., Requena, J.R., Wille, H., 2017. The Structure of Mammalian Prions and Their Aggregates. Int Rev Cell Mol Biol 329, 277-301.

Verma, M., Vats, A., Taneja, V., 2015. Toxic species in amyloid disorders: Oligomers or mature fibrils. Ann Indian Acad Neurol 18, 138-145.

Wallin, C., Hiruma, Y., Wärmländer, S., Huvent, I., Jarvet, J., Abrahams, J.P., Gräslund, A., Lippens, G., Luo, J., 2018. The Neuronal Tau Protein Blocks in Vitro Fibrillation of the Amyloid-beta (Abeta) Peptide at the Oligomeric Stage. J Am Chem Soc 140, 8138-8146.

Wallin, C., Luo, J., Jarvet, J., Wärmländer, S.K.T.S., Gräslund, A., 2017. The Amyloid-b Peptide in Amyloid Formation Processes: Interactions with Blood Proteins and Naturally Occurring Metal Ions. Israel Journal of Chemistry 57, 674-685.

Wang, C., lashchishyn, I.A., Kara, J., Fodera, V., Vetri, V., Sancataldo, G., Marklund, N., MorozovaRoche, L.A., 2019. Proinflammatory and amyloidogenic S100A9 induced by traumatic brain injury in mouse model. Neurosci Lett 699, 199-205.

Wang, C., Klechikov, A.G., Gharibyan, A.L., Wärmländer, S.K.T.S., Jarvet, J., Zhao, L., Jia, X., Narayana, V.K., Shankar, S.K., Olofsson, A., Brännström, T., Mu, Y., Gräslund, A., Morozova-Roche, L.A., 2014. The role of pro-inflammatory S100A9 in Alzheimer's disease amyloidneuroinflammatory cascade. Acta Neuropathol 127, 507-522.

Wang, G., Li, X., Wang, Z., 2016. APD3: the antimicrobial peptide database as a tool for research and education. Nucleic Acids Res 44, D1087-1093.

Wimley, W.C., White, S.H., 1996. Experimentally determined hydrophobicity scale for proteins at membrane interfaces. Nat Struct Biol 3, 842-848.

Wärmländer, S.K.T.S., Tiiman, A., Abelein, A., Luo, J., Jarvet, J., Söderberg, K.L., Danielsson, J., Gräslund, A., 2013. Biophysical studies of the amyloid beta-peptide: interactions with metal ions and small molecules. Chembiochem 14, 1692-1704.

Wärmländer, S.K.T.S., Österlund, N., Wallin, C., Wu, J., Luo, J., Tiiman, A., Jarvet, J., Gräslund, A., 2019. Metal binding to the amyloid-beta peptides in the presence of biomembranes: potential mechanisms of cell toxicity. J Biol Inorg Chem 24, 1189-1196.

Yamaguchi, K.I., Kuwata, K., 2018. Formation and properties of amyloid fibrils of prion protein. Biophys Rev 10, 517-525.

Zahn, R., von Schroetter, C., Wüthrich, K., 1997. Human prion proteins expressed in Escherichia coli and purified by high-affinity column refolding. FEBS Lett 417, 400-404.

Österlund, N., Kulkarni, Y.S., Misiaszek, A.D., Wallin, C., Kruger, D.M., Liao, Q., Mashayekhy Rad, F., Jarvet, J., Strodel, B., Wärmländer, S.K.T.S., Ilag, L.L., Kamerlin, S.C.L., Gräslund, A., 2018. Amyloid-beta Peptide Interactions with Amphiphilic Surfactants: Electrostatic and Hydrophobic Effects. ACS Chem Neurosci 9, 1680-1692. 